\title{
Polyhydroxybutyrate (PHB) Production by Bacteria and its Application as Biodegradable Plastic in Various Industries
}

\author{
Neha Sharma* \\ Department of Bioscience \& Biotechnology, Banasthali University, India
}

Submission: January 25, 2019; Published: February 04, 2019

*Corresponding author: Neha Sharma, Department of Bioscience \& Biotechnology, Banasthali University, Rajasthan, India

\begin{abstract}
Commercially available plastics are commonly used in day to day life. The rate of accumulation of plastic in the environment is increasing day by day which becomes a major universal concern due to its less biodegradation property. Generated plastic waste is managed by incineration or landfill disposal. These processes are time -consuming and expensive. The main objective of the study involves the investigation bio-degradable polymers viz Polyhydroxybutyrate (PHB) produced by bacterial species (Alcaligenes). The stock culture of Alcaligenes species was cultured at a rate of $5 \%$ in production media containing $2.5 \%$ of sucrose. The growth was quantified through optical density, biomass and PHB. The biomass of the culture was $2.7 \mathrm{~g} / \mathrm{l}$. The growth curve was obtained that was following the same trend. The PHB was estimated through gas chromatography. The biodegradable plastic was significantly produced by bacteria in the production media that has potential in medical applications, including drug delivery and medical implants.
\end{abstract}

Keywords: Polyhydroxybutyrate; Polymers; Biodegradable

Abbreviations: PHB: Polyhydroxybutyrate; PHBV: Hydroxybutyrate-Co-Hydroxy Valerate; PHBHHx: Hydroxybutyrate-Co-Hydroxy Hexanoate; PHO: Polyhydroxy Octanoate; PP: Polypropylene; PE: Polyethylene; DCE: Dichloroethane

\section{Introduction}

Petroleum-derived plastics (commercially available) have become an integral part of our modern life which successfully replacing various other products over the years. From automobiles to medicine, plastics are utilized in almost every manufacturing industry in the world. Approximately 25 million tons of plastics are produced by the plastics industry every year [1]. The consistent dependency on commercial non-biodegradable plastics causes an adverse impact on environment viz. crude oil reduction and pollution. Disposal of plastic waste through incineration may generate toxic products and is expensive thermal process and recycling can be done but it is time -consuming process and alterations may occur in the plastics with time.

To overcome the hazardous impact of commercial plastics, there is an alternative of biopolymers such as aliphatic polyesters, polylactide, and polyhydroxyalkanoates. Polyhydroxybutyrate (PHB) is one of the members of polyhydroxyalkanoates are the more promising candidate due to its biodegradable and eco- friendly property [2]. Polyhydroxybutyrate is produced by bacteria, fungi, molds etc. Polyhydroxybutyrate is eco-friendly plastic which has a wide range of applications. These lipid inclusions are accumulated in the bacteria as they entered the stationary phase of growth. Under limited nitrogen condition and in the presence of carbon source, some bacteria accumulate around $60-80 \%$ of their weight as PHB. Polyhydroxyalkanoates (PHAs) are polyesters synthesized by various microorganisms, such as Ralstonia eutropha, Alcaligenes latus, Aeromonas hydrophila, Pseudomonas putida and Bacillus [3-7].

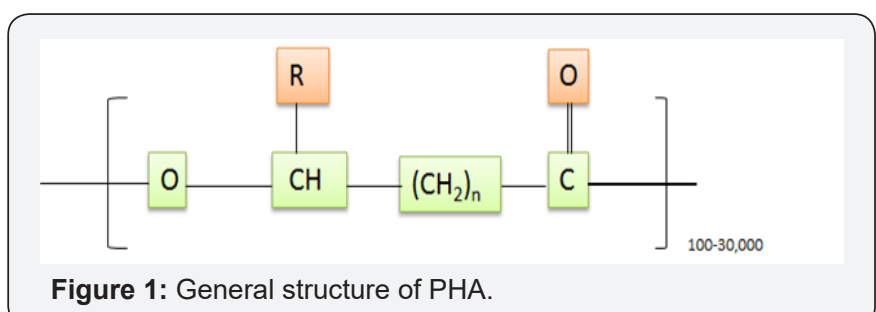

The PHAs are classified by the number of carbon atoms in their monomers. In "short-chain length" PHAs, such as atalysed l utyrate (PHB) and polyhydroxyvalerate, carbon numbers of monomers are 3 to 5 whereas, carbon numbers in medium chain-length PHA monomers range from 6 to 16. In addition to PHB, more than 140 different PHAs have been identified (Figure 1). The PHA types, such as atalysed l utyrate (PHB), poly (Hydroxybutyrate-Co-Hydroxy Valerate) (PHBV), Poly (Hydroxybutyrate-Co-Hydroxy hexanoate) (PHBHHx) 
and Polyhydroxy Octanoate (PHO) are frequently studied for biomedical applications including tissue regeneration devices, repair devices, repair patches and sutures [8-11].

PHB has been the most promising biodegradable plastics and as an alternative to petrochemical plastics. This is due to their biocompatibility, biodegradability and versatile properties make it an eco-friendly substitute for synthetic polymers [12]. The molecular weight varies from $2-3 \times 103 \mathrm{~K}$ Da. The weight was depending on the species that actually producing the polymer [13]. PHB has more advantages because it is far less permeable than PE and PP, this known as a better material for food packaging needless to use antioxidant. Some industrial applications of PHB have been hampered owing to its low thermal stability and excessive brittleness upon storage. The main fermentation strategies used to obtain bio-products are batch culture, fed-batch culture, continuous culture and twostage fermentation. Two-stage fermentation is currently the most common method of producing PHAs. In the first stage of the proposed process, biomass is increased to the level needed for PHB production. In the second stage, nutrients are limited in order to stimulate PHB synthesis by bacteria. This study also applied a two-stage fermentation strategy.

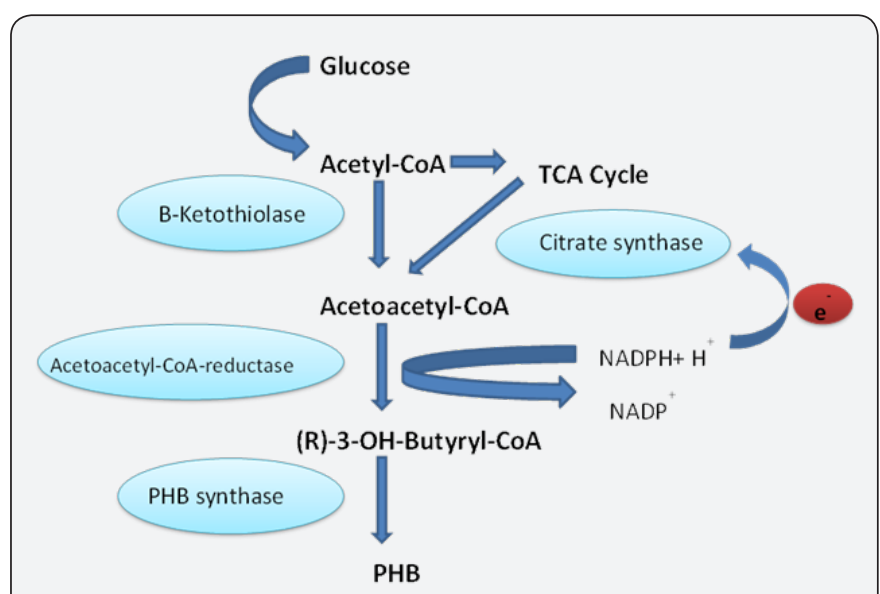

Figure 2: Biosynthetic pathway of atalysed I utyrate from acetylCoA.

PHB is produced by many genera of bacteria as inclusion bodies to serve as a carbon source and electron sink. PHB is synthesized from acetyl-CoA produce by the bacteria in the sequential action of three enzymes. 3-ketothiolase (phbA gene) catalysis the formation of a carbon-carbon bond by condensation of two acetyl-CoA NADPH dependent atalysed l-CoA reductase (phbB gene) catalyses the stereoselective reduction of atalysed l-CoA formed in the first reaction to R-3- hydroxy butyryl CoA. The third reaction of this pathway is atalysed by the enzyme PHB synthase (phbC gene) that catalyzes the polymerization of R-3- hydroxy butyryl- CoA to form PHB. The EC number is yet to be assigned to PHA synthase [14]. The biosynthetic pathway of PHB from acetyl-CoA was shown in Figure 2. PHB is a partially crystalline polymer which has material properties similar to Polypropylene (PP) and Polyethylene (PE) [15,16].
In this investigation, the efficiency of selected microorganism was evaluated towards the generation of PHB. The culture revived and quantified for various parameters including biomass, optical density and polymer (PHB) through gas chromatography.

\section{Materials and Methods}

The micro-organism was received from ATCC. The microorganism was stored in nutrient agar slants. The Alcaligenes was cultured in $50 \mathrm{ml}$ of nutrient broth. After the seed culture was developed it was subculture at a rate of $5 \%$ in production media (2.5\% sucrose). Optical Density (OD) was measured at $600 \mathrm{~nm}$ in a UVIKON 930 spectrophotometer (Kontron Instruments, USA). The dry cell mass (biomass) was also estimated.

The content of PHB in the dried cells was estimated by gas chromatography (Nucon gas chromatograph 5765, AIMIL, India) with benzoic acid as an internal standard; $40 \mathrm{mg}$ of dried cells was dissolved in $2 \mathrm{~mL}$ of 1, 2-Dichloroethane (DCE) and $2 \mathrm{~mL}$ of acidified propanol and $200 \mu \mathrm{L}$ of internal standard. PHB was thus converted to the propyl ester of Hydroxybutyric Acid (HBA). After cooling to room temperature, $4 \mathrm{~mL}$ of distilled water was added, and the mixture was shaken for 20-30 seconds. The heavier phase (DCE-propanol) was injected into the gas chromatograph column (2\% Reoplex on chromosorb).

\section{Results}

In the present investigation, the gradual increase in the optical density was monitored till 30 hours after that stationary phase was observed with constant OD at $600 \mathrm{~nm}$. The dried mass of the cell pellet was around $2.7 \mathrm{~g} / \mathrm{l}$ in the shake flask experiment. The PHB was $2.1 \mathrm{~g} / \mathrm{l}$ in the lab scale experiment. The PHB was focused in this study due to various advantages such as ecofriendly behavior, non-toxic, biodegradable. There are various reports that clearly depict the generation of bio-plastics from the renewable substrates [17].

\section{Discussion}

The biodegradable plastic can have various applications: firstly, bioplastic can be used to develop agricultural and construction materials, automotive interior materials, electrical devices, bottles, containers etc. PHB is compatible with the body tissues that make their application in medical, pharmaceutical areas such as surgical sutures, wound dressings and ocular devices. PHB can be used as a packaging material [18] studied the effect of pasteurization on a meat salad packaged in the PHB film and found it to be a significant aspirant in packaging material $[18,19]$.

\section{Conclusion}

The results of this study confirmed that the biodegradable plastic can be easily produced in the production media and also be quantified that reduces environmental pollution problems caused by conventional plastics and solving disposal problem of the agricultural wastes. 


\section{Acknowledgements}

The author is thankful to IIT, Delhi for providing necessary facilities to observe the biodegradable plastics.

\section{References}

1. Wong PA, Chua H, Lo W, Lawford HG, Yu PH (2002) Production of specific copolymers of polyhydroxyalkanoates from industrial waste. Appl Biochem. Biotechnol 98(100): 655-662.

2. Salehizadeh H, Van Loosdrecht, MCM (2004) Biotechnol. Adv 22:261279 .

3. Chakraborty P, Gibbons W, Muthukumarappanl K (2009) Conversion of volatile fatty acids into polyhydroxyalkanoate by Ralstonia eutropha. J Appl Microbio 106: 1996-2005.

4. Yu PH, Chua H, Huang AL, Ho KP (1999) Conversion of industrial food wastes by Alcaligenes latus into polyhydroxyalkanoates. Appl Biochem Biotechnol 77(79): 445-454.

5. Zhang HF, Ma L, Wang ZH, Chen GQ (2009) Biosynthesis and characterization of 3-hydroxyalkanoate terpolyesters with adjustable properties by Aeromonas hydrophila. Biotechnol Bioeng 104(3): 582589

6. Ren Q, de Roo G, Witholt B, Zinn M, Thony Meyer L (2010) Influence of growth stage on activities of polyhydroxyalkanoate (PHA) polymerase and PHA depolymerase in Pseudomonas putida U. BMC Microbiol 10 254

7. Singh M, Patel SK, Kalia VC (2009) Bacillus subtilis as potential producer for polyhydroxyalkanoates. Microb Cell Fact 8: 38

8. Dong Y, Li P, Chen CB, Wang ZH, Ma P, et al. (2010) The improvement of fibroblast growth on hydrophobic biopolyesters by coating with polyhydroxyalkanoate granule binding protein PhaP fused with cell adhesion motif RGD. Biomaterials 31(34): 8921-8930.
9. Cousley RR (2009) A stent-guided mini-implant system. J Clin Orthod 43(6): 403-407.

10.Xu XY, Li XT, Peng SW, Xiao JF, Liu C, et al. (2010) The behaviour of neural stem cells on polyhydroxyalkanoate nanofiber scaffolds. Biomaterials 31: 3967-3975.

11. Han I, Shim KJ, Kim JY, Im SU, Sung YK, et al. (2007) Effect of poly(3-hydroxybutyrate-co-3-hydroxyvalerate) nanofiber matrices cocultured with hair follicular epithelial and dermal cells for biological wound dressing. Artif Organs 31(11): 801-808.

12. Brandl H, Gross RA, Lenz RW, Fuller RC (1988) Pseudomonas oleovorans as a source of Poly hydroxyalkanotes for potential applications as biodegradable polyesters. Appl Environ Microbiol 54(8): 1977-1982.

13. Saharan BS, Sharma AS, (2012). Bioplastics-For sustainable development: A Review. Interntional Journal of Microbial Resource Technology 1:11-23.

14. Steinbuchel A, Valentin HE (1995) Diversity of bacterial polyhydroxyalkanoic acids. FEMS Microbiology Letters 128(3): 219228.

15. Holmes PA (1988) Biologically produced PHA polymers and copolymers, Developments in crystalline polymers. London, England: Elsevier 2: 1-65.

16. Lee SY (1996) Plastic bacteria? Progress and prospects for polyhydroxy alkanoate production in bacteria. TIBTECH 14(11): 431-438.

17. Getachew A, Woldesenbet F (2016) Production of biodegradable plastic by polyhydroxybutyrate (PHB) accumulating bacteria using low cost agricultural waste material. BMC Research Notes 9: 509.

18. Levkane V, Muizniece BS, Dukalska L (2008) Pasteurization effect to quality of salad with meat and mayonnaise. Foodbalt 69-73.

19. Chen GQ (2009) A microbial polyhydroxyalkanoates (PHA) based bioand materials industry. Chem Soc Rev 38(8): 2434-2446.

\section{Your next submission with Juniper Publishers} will reach you the below assets

- Quality Editorial service

- Swift Peer Review

- Reprints availability

- E-prints Service

- Manuscript Podcast for convenient understanding

- Global attainment for your research

- Manuscript accessibility in different formats

( Pdf, E-pub, Full Text, Audio)

- Unceasing customer service

Track the below URL for one-step submission

https://juniperpublishers.com/online-submission.php 